\title{
Przestrzenne zróżnicowanie produkcji biomasy rolniczej pochodzenia roślinnego w państwach UE w kontekście rozwoju biogospodarki
}

\section{Spatial Diversification of Agricultural Biomass Production of Plant Origin in EU Countries in the Context of Bioeconomy Development}

\begin{abstract}
Synopsis. Celem artykułu była identyfikacja i ocena przestrzennego zróżnicowania produkcji biomasy rolniczej pochodzenia roślinnego w państwach UE, jako podstawowego surowca wykorzystywanego do wytwarzania bioproduktów oraz bioenergii. W opracowaniu wykorzystano dane statystyczne pozyskane z EUROSTATU. Okres badawczy obejmował 2015 rok. Do interpretacji badań zastosowano statystykę opisową i parametryczną, wykorzystano wskaźniki struktury, gęstości i natężenia, a także wskaźnik korelacji Pearsona. W toku badań stwierdzono, że w 2015 roku 51,5\% wytwarzanej w UE biomasy roślinnej w rolnictwie to produkty uboczne - pochodzące $\mathrm{z}$ resztek roślin uprawnych, $\mathrm{z}$ roślin pastewnych i biomasy wypasanej. Produkcja biomasy roślinnej cechowała się znacznym zróżnicowaniem przestrzennym zarówno w odniesieniu do biomasy pochodzącej z roślin uprawnych (liderami w tym zakresie były kraje: Francja, Niemcy, Hiszpania, Włochy i Polska), jak i do pozostałej biomasy (największy udział miały: Niemcy, Francja, Polska, Wielka Brytania i Włochy). W 2015 roku na terenie siedmiu krajów (tj. Niemiec, Francji, Polski, Wielkiej Brytanii, Hiszpanii, Włoch i Rumunii) wyprodukowano łącznie blisko 3/4 roślinnej biomasy wytwarzanej w UE. Analizom poddano również zależności pomiędzy wielkością produkcji biomasy, potencjałem ludnościowym kraju (mierzonym udziałem w liczbie ludności UE) i potencjałem produkcyjnym rolnictwa (mierzonym udziałem w powierzchni użytków rolnych w UE), co pozwoliło na wyznaczenie czterech grup państw.
\end{abstract}

Slowa kluczowe: biomasa, biogospodarka, państwa Unii Europejskiej, zróżnicowanie przestrzenne

\begin{abstract}
The aim of the article was to identify and assess the spatial diversity of agricultural biomass production of plant origin in EU countries as the basic raw material used to create bioproducts and bioenergy. The study uses statistical data obtained from EUROSTAT. The research period covered 2015. Descriptive and parametric statistics were used to interpret the study, and also the indicators of structure, density and intensity were used, as well as the Pearson correlation coefficient. The study found that in 2015 about $51,5 \%$ of plant biomass in agriculture produced in the EU were by-products derived from crop residues, fodder crops and grazed biomass. The production of plant biomass was characterized by considerable spatial differentiation both in relation to biomass derived from arable crops (the leaders in this respect were: France, Germany, Spain, Italy and Poland) as well as to other biomass (Germany, France, Poland, Great Britain and Italy had the largest share). In 2015, nearly $3 / 4$ of the plant biomass produced in the EU was produced in seven countries (i.e. Germany, France, Poland, Great Britain, Spain, Italy and Romania). The analysis also included the dependences among the size of biomass production, the population potential of the country (measured by the share in the EU population) and the production potential of agriculture (measured in the share of agricultural land in the EU). This allowed the designation of four groups of countries.
\end{abstract}

Key words: biomass, bioeconomy, Eropean Union countries, spatial diversity

JEL Classification: O13, Q57, Q21, R32

\footnotetext{
${ }^{1}$ dr, Katedra Zarządzania i Marketingu, Uniwersytet Przyrodniczy w Lublinie, ul. Akademicka 13, 20-950 Lublin, e-mail: agnieszka.komor@up.lublin.pl
} 


\section{Wprowadzenie}

W ostatnich latach wzrosło zainteresowanie koncepcją biogospodarki bazująca na wykorzystaniu zasobów odnawialnych i wiedzy. Kluczowym elementem tych zasobów jest biomasa, w tym biomasa pochodząca $\mathrm{z}$ rolnictwa. Stąd w niniejszym opracowaniu podjęto próbę prezentacji i systematyzacji różnych podejść do definiowania pojęcia biomasy, a także przedstawienia znaczenia biomasy w kreowaniu rozwoju opartego o koncepcję biogospodarki.

Celem niniejszego opracowania była identyfikacja i ocena przestrzennego zróżnicowania produkcji biomasy rolniczej pochodzenia roślinnego w państwach UE, jako podstawowego surowca wykorzystywanego do wytwarzania bioproduktów oraz bioenergii.

W pracy wykorzystano dane statystyczne z systemu ogólnogospodarczych rachunków przepływów materialnych (EW-MFA) pochodzace z EUROSTAT. Analizom poddano strukturę wolumenu wytworzonej biomasy pozyskanej z roślin uprawnych oraz pozostałej biomasy (resztki roślin uprawnych, rośliny pastewne i biomasa wypasana) w ramach UE, wielkość krajowego pozyskania biomasy w przeliczeniu na mieszkańca oraz na hektar użytków rolnych. Wyniki analiz zaprezentowano w formie tabelarycznej i graficznej. Do interpretacji wyników badań zastosowano statystykę opisową i parametryczną.

\section{Znaczenie biomasy rolniczej w rozwoju biogospodarki}

Biomasa stanowi istotny element zasobów naturalnych, w skład których wchodzą nieodnawialne zasoby abiotyczne (np. gleby, minerały, ukształtowanie powierzchni terenu, przestrzeń - obszar ziemi), odnawialne zasoby abiotyczne (np. wody powierzchniowe, wody gruntowe, woda morska, klimat, wiatr, słońce, energia geotermalna, słoneczna, wiatru oraz pływów), a także odnawialne zasoby biotyczne (np. biomasa z wypasu, biomasa ze zbiorów, biomasa $\mathrm{z}$ leśnictwa, biomasa $\mathrm{z}$ polowań, biomasa $\mathrm{z}$ połowów, lądowa różnorodność biologiczna, różnorodność biologiczna wód słodkich, mórz i gleb) (Christmann, 2004).

W przepisach prawnych oraz w innych dokumentach można odnaleźć różne definicje biomasy (tabela 1.). Analizując definicje zawarte w tabeli 1. należy zauważyć, że źródłem biomasy są produkty, odpady i pozostałości pochodzące z rolnictwa, leśnictwa, rybołówstwa, akwakultury, a także z produkcji przemysłowej (w tym przemysłu spożywczego) i gospodarki komunalnej pod warunkiem ich organicznego pochodzenia i biodegradowalności. Biomasa może być wykorzystywana jako produkt finalny lub stanowić surowiec do wytwarzania innych produktów, tj. żywności, bioenergii oraz biomateriałów.

Przedmiotem badań w niniejszym opracowaniu jest rolnicza biomasa roślinna. Pomimo występującej tendencji związanej ze zmniejszaniem się udziału wartości dodanej wytworzonej $\mathrm{W}$ rolnictwie $\mathrm{w}$ strukturze PKB wraz wzrostem poziomu rozwoju gospodarczego poszczególnych państw (Jarosz-Angowska, 2015) warto zauważyć, że biomasa rolnicza ma bardzo szerokie zastosowanie w gospodarce, jako istotny element zasobów odnawialnych. W sposób szczególny rola biomasy w kreowaniu rozwoju społeczno-gospodarczego oraz dobrobytu ludności podkreślana jest w ramach koncepcji biogospodarki.

Podstawowym zastosowaniem biomasy rolniczej pozostaje produkcja żywności i zabezpieczenie bezpieczeństwa żywnościowego ludności. Jak zauważa J. Wilkin (2010) ze względu na charakter dóbr wytwarzanych przez rolnictwo, w tym szczególnie 
produktów żywnościowych, ma ono decydujące znaczenie w życiu społeczeństw, nawet jeśli wytwarza niewielki odsetek dochodu narodowego. Ponadto biomasa tego typu jest wykorzystywana m.in. do produkcji pasz, energii, odzieży, kosmetyków, farmaceutyków czy nawozów. Może to implikować konkurencję pomiędzy różnymi zastosowaniami biomasy pozyskiwanej $\mathrm{z}$ rolnictwa. Warto zauważyć, że do produkcji biomasy wykorzystuje się znaczne ilości wody i użytków rolnych. Stąd też cele UE dotyczące zwiększenia ilości wytwarzanej biomasy, a co za tym idzie wzrostu produkcji rolnej, niosą również zagrożenia dotyczące niepożądanych zmian w użytkowaniu gruntów, gospodarowania zasobami wodnymi czy zachowania bioróżnorodności. Ważne znaczenie ma jednak zwiększenie wolumenu produktów wytwarzanych $\mathrm{z}$ biomasy $\mathrm{w}$ celu stopniowego zastępowania nimi produktów opartych na paliwach kopalnych.

Tabela 1. Wybrane definicje biomasy

Table 1. Selected biomass definitions

\begin{tabular}{|c|c|}
\hline Źródło definicji & Biomasa: \\
\hline $\begin{array}{l}\text { Rozporządzenie } \\
\text { Ministra Gospodarki } \\
\text { z dnia } \\
18 \text { października } \\
2012 \text { r. }\end{array}$ & $\begin{array}{l}\text { to stałe lub ciekłe substancje pochodzenia ró́linnego lub zwierzęcego, które ulegają } \\
\text { biodegradacji, pochodzące z produktów, odpadów i pozostałości z produkcji rolnej } \\
\text { i leśnej oraz przemysłu przetwarzającego ich produkty, a także części pozostałych } \\
\text { odpadów, które ulegają biodegradacji, oraz ziarna zbóż niespełniające wymagań } \\
\text { jakościowych dla zbóż w zakupie interwencyjnym określonych w art. } 7 \text { rozporządzenia } \\
\text { Komisji (WE) nr } 1272 / 2009 \text { z dnia } 11 \text { grudnia } 2009 \mathrm{r} \text {. ustanawiającego wspólne } \\
\text { szczegółowe zasady wykonania rozporządzenia Rady (WE) nr } 1234 / 2007 \text { w odniesieniu } \\
\text { do zakupu i sprzedaży produktów rolnych w ramach interwencji publicznej (Dz. Urz. } \\
\text { UE L } 349 \text { z } 29.12 .2009 \text {, str. 1, z późn. zm.) i ziarna zbóż, które nie podlegają zakupowi } \\
\text { interwencyjnemu. }\end{array}$ \\
\hline $\begin{array}{l}\text { Ustawa z dnia } \\
25 \text { sierpnia } 2006 \mathrm{r} \text {. } \\
\text { o biokomponentach } \\
\text { i biopaliwach } \\
\text { ciekłych }\end{array}$ & $\begin{array}{l}\text { to ulegające biodegradacji części produktów, odpady lub pozostałości pochodzenia } \\
\text { biologicznego z rolnictwa, łącznie z substancjami roślinnymi i zwierzęcymi, leśnictwa } \\
\text { i rybołówstwa oraz powiązanych z nimi działów przemysłu, w tym z chowu i hodowli } \\
\text { ryb oraz akwakultury, a także ulegająca biodegradacji część odpadów przemysłowych } \\
\text { i komunalnych, w tym z instalacji służących zagospodarowaniu odpadów oraz } \\
\text { uzdatniania wody i oczyszczania ścieków. }\end{array}$ \\
\hline OECD 2004, s. 17 & $\begin{array}{l}\text { to każdy materiał organiczny pochodzenia roślinnego i zwierzęcego pochodzący } \\
\text { z produkcji rolnej i leśnej oraz powstałych produktów ubocznych, a także odpadów } \\
\text { przemysłowych i miejskich, wykorzystywany jako surowiec do produkcji bioenergii } \\
\text { i biomateriałów }\end{array}$ \\
\hline $\begin{array}{l}\text { Dyrektywa } \\
\text { Parlamentu } \\
\text { Europejskiego i Rady } \\
\text { 2009/28/WE }\end{array}$ & $\begin{array}{l}\text { to ulegająca biodegradacji część produktów, odpadów lub pozostałości pochodzenia } \\
\text { biologicznego z rolnictwa (łącznie z substancjami roślinnymi i zwierzęcymi), leśnictwa } \\
\text { i związanych działów przemysłu, w tym rybołówstwa i akwakultury, a także ulegającą } \\
\text { biodegradacji część odpadów przemysłowych i miejskich }\end{array}$ \\
\hline EUROSTAT, 2018b & $\begin{array}{l}\text { to organiczny, niekopalny materiał pochodzenia biologicznego, który może być } \\
\text { wykorzystywany jako biogenny surowiec do produkcji żywności, innych produktów } \\
\text { oraz do wytwarzania energii w postaci ciepła lub energii elektrycznej. }\end{array}$ \\
\hline $\begin{array}{l}\text { The European } \\
\text { Bioeconomy..., } 2011\end{array}$ & $\begin{array}{l}\text { (odnawialna) obejmuje każdy materiał biologiczny jako produkt lub jako surowiec } \\
\text { wykorzystywany do wytwarzania innych produktów. }\end{array}$ \\
\hline
\end{tabular}

Źródło: Rozporządzenie Ministra Gospodarki z dnia 18 października 2012 r. ...; Ustawa z dnia 25 sierpnia 2006 r. o biokomponentach i biopaliwach ciekłych ...; OECD 2004, s. 17; Dyrektywa Parlamentu Europejskiego i Rady 2009/28/WE ...; EUROSTAT, 2018b; The European Bioeconomy..., 2011.

Rola biomasy rolniczej w biogospodarce polega na produkcji surowców, które na skutek zastosowania odpowiednich procesów (np. fermentacji czy spalania) są 
przekształcane $w$ bioenergię oraz bioprodukty. Bioenergia wytwarzana $\mathrm{z}$ biomasy rolniczej obejmuje biopaliwa transportowe wytwarzane na bazie ziaren zbóż i cukru (np. bioetanol) oraz olejów roślinnych i tłuszczów zwierzęcych (biodiesel). Energia elektryczna i cieplna jest wytwarzana $\mathrm{z}$ produktów rolno-leśnych (np. wierzby), produktów ubocznych pozyskiwanych z upraw i od zwierząt gospodarskich (np. słomy i nawozów pochodzenia zwierzęcego) oraz traw. Biomasa rolnicza służy również do wytwarzania biomateriałów, tj. m.in. oleje przemysłowe pochodzące $\mathrm{z}$ upraw roślin oleistych wykorzystywane są do produkcji smarów, farb, tuszów, itp.; skrobia i cukier pochodzące np. ze zbóż, ziemniaków, buraków cukrowych i trzciny cukrowej są stosowane do produkcji polimerów, detergentów, farmaceutyków, papieru, dodatków zdrowotnych, itp.; włókna pozyskiwane z roślin uprawnych takich jak np. bawełna, len i konopie służą do produkcji tkanin i papieru. Inne produkty pochodzące $\mathrm{z}$ różnych upraw są stosowane $\mathrm{w}$ produkcji np. kosmetyków, farmaceutyków, dodatków zdrowotnych, smakowych, aromatyzujących, produktów do konserwacji żywności oraz środków ochrony roślin (OECD 2004, s. 17, 28).

\section{Dane i metody}

Dane statystyczne wykorzystane $\mathrm{w}$ niniejszym opracowaniu zaczerpnięto $\mathrm{z}$ systemu ogólnogospodarczych rachunków przepływów materialnych (EW-MFA), które stanowia element europejskich rachunków ekonomicznych środowiska. Rachunki EW-MFA obejmują wszystkie materiały stałe, gazowe i ciekłe (z wyjątkiem przepływów powietrza i wody), mierzone w jednostkach masy rocznie. Do materiałów zalicza się: surowce, materiały nieprzetworzone lub pierwotne. Rachunki mierzą przepływy materialne (przekraczające granice systemów) do i z gospodarki oraz zmianę zapasów w gospodarce. Stąd nie uwzględnia się w nich międzybranżowych dostaw produktów czy też przepływów $\mathrm{w}$ obrębie środowiska naturalnego mających miejsce w ramach gospodarki narodowej. W skład rachunków przepływów materialnych wchodzą: przepływy między gospodarką narodową a jej środowiskiem naturalnym obejmujące pozyskanie krajowe (tj. roczną ilość materiałów pozyskanych ze środowiska naturalnego, traktowanych jako wkłady materialne do gospodarki) oraz uwalnianie materiałów do środowiska, a także przepływy materialne między gospodarką narodową a pozostałą gospodarką światową (tj. import i eksport towarów w jednostkach masy na wszystkich etapach obróbki - od surowców po wyroby gotowe) (Rozporządzenie Parlamentu Europejskiego i Rady (UE) nr 691/2011).

W niniejszym artykule analizom poddano dane dotyczące krajowego pozyskania (produkcji) biomasy roślinnej przez jednostki będące rezydentami ze środowiska naturalnego do dalszego przetwarzania w gospodarce. Nie uwzględniono danych dotyczących handlu zagranicznego biomasa, przy czym warto zauważyć, że jego znaczenie w ostatnich latach wzrasta (Heinimö i Junginger, 2009; Gradziuk i Gradziuk, 2015).

$\mathrm{W}$ ramach biomasy roślinnej wyróżnić można biomasę pochodząca $\mathrm{z}$ roślin uprawnych (z wyjątkiem roślin pastewnych) oraz pozostałą biomasę roślinną. Do pierwszej grupy zaliczają się: zboża, korzenie i bulwy, uprawy cukrowe, rośliny strączkowe, orzechy, rośliny oleiste, warzywa, owoce, rośliny włókniste oraz pozostałe rośliny uprawne gdzie 
indziej niewymienione. ${ }^{2}$ Do pozostałej biomasy zaliczono: resztki roślin uprawnych (słoma i inne resztki roślin uprawnych takie jak m.in. liście buraków cukrowych i pastewnych), rośliny pastewne (np. biomasa z użytków zielonych) i biomasę wypasaną (Rozporządzenie Parlamentu Europejskiego i Rady (UE) nr 691/2011).

Dane statystyczne wykorzystane do identyfikacji i oceny przestrzennego zróżnicowania produkcji biomasy rolniczej pochodzenia roślinnego zostały pozyskane z EUROSTATU. Okres badawczy obejmował 2015 rok. Wyniki zaprezentowano w formie tabelarycznej i graficznej. Do interpretacji badań zastosowano statystykę opisową i parametryczną. W pracy analizowano wskaźniki struktury, gęstości i natężenia, jak również wskaźnik korelacji Pearsona.

\section{Produkcja biomasy rolniczej pochodzenia roślinnego w państwach UE w 2015 roku}

$\mathrm{W}$ pierwszej kolejności analizom poddano biomasę roślinną pochodzącą z roślin uprawnych (z wyjątkiem roślin pastewnych). W 2015 roku w krajach UE wyprodukowano łącznie 669 207,11 tys. ton biomasy pochodzącej z roślin uprawnych (co stanowiło 48,5\% biomasy roślinnej ogółem). Warto zauważyć, że ponad połowa wytwarzanej w UE biomasy roślinnej $\mathrm{w}$ rolnictwie $(51,5 \%)$ to produkty uboczne. Ma to szczególne znaczenie w kontekście toczącej się dyskusji dotyczącej wykorzystania biomasy rolniczej na cele nieżywnościowe (tj. bioprodukty i bioenergię), która budzi rozliczne kontrowersje natury etycznej, ekonomicznej czy środowiskowej. Stąd też wydaje się, że produkty uboczne rolnictwa powinny być w pierwszej kolejności zagospodarowane na cele nieżywnościowe.

W 2015 roku największy udział w unijnym wolumenie pozyskiwanej biomasy z roślin uprawnych miała Francja $(20,9 \%)$, Niemcy $(14,4 \%)$, Hiszpania $(9,9 \%)$, Włochy $(8,7 \%)$ oraz Polska $(8,2 \%)$ - tabela 2 . Są to państwa mające wieloletnie tradycje $\mathrm{w}$ zakresie produkcji rolnej, o relatywnie dużej liczbie ludności, powierzchni ogółem oraz powierzchni użytków rolnych. Łączny udział pięciu omawianych krajów w wolumenie biomasy pochodzącej $\mathrm{z}$ roślin uprawnych produkowanej we wszystkich państwach Unii Europejskiej wynosił $62,1 \%$, co świadczy o względnie dużym stopniu koncentracji przestrzennej analizowanego zjawiska. W tym kontekście można stwierdzić, że są to kraje predestynowane do oparcia rozwoju o koncepcję biogospodarki. Warto podkreślić, że relatywnie wysoka lokata Polski wynikała ze znacznego udziału krajowej produkcji roślin okopowych, buraków cukrowych i zbóż w produkcji unijnej (odpowiednio 11,3\%, 8,9\% i 8,8\%).

W 2015 roku w UE wolumen rolniczej biomasy pozyskanej z roślin uprawnych w przeliczeniu na mieszkańca wynosił średnio $1314 \mathrm{~kg}$ (tabela 2). Najwyższą wartość omawianego wskaźnika odnotowano na Litwie $(2887 \mathrm{~kg})$, w Danii $(2731 \mathrm{~kg})$, na Węgrzech $(2122 \mathrm{~kg})$, we Francji $(2098 \mathrm{~kg})$ oraz na Łotwie $(2077 \mathrm{~kg})$. Wysoka wartość wskaźnika w odniesieniu do Łotwy i Litwy była związana ze stosunkowo niewielkim udziałem tych państw w liczbie mieszkańców UE. W pozostałych krajach wartość ta nie przekraczała $2000 \mathrm{~kg}$ na mieszkańca. Polska w tym rankingu uplasowała się na dziewiątej pozycji z wartością $1437 \mathrm{~kg}$ per capita.

\footnotetext{
${ }^{2}$ W polskim nazewnictwie, w tym także wykorzystywanym przez GUS, stosuje się następujące nazwy: zboża, okopowe, uprawy cukrowe, strączkowe, orzechy, oleiste, warzywa, owoce, włókniste oraz pozostałe rośliny uprawne gdzie indziej niewymienione.
} 
Tabela 2. Produkcja rolniczej biomasy pochodzenia roślinnego w państwach UE w 2015 roku

Table 2. Production of agricultural biomass of plant origin in EU countries in 2015

\begin{tabular}{|c|c|c|c|c|c|c|c|c|}
\hline \multirow{2}{*}{ Państwa UE } & \multicolumn{4}{|c|}{$\begin{array}{l}\text { Biomasa pochodzenia rolniczego z roślin } \\
\text { uprawnych }\end{array}$} & \multicolumn{4}{|c|}{$\begin{array}{c}\text { Pozostała roślinna biomasa pochodzenia } \\
\text { rolniczego }\end{array}$} \\
\hline & tys. ton & $\begin{array}{c}\%, \\
\text { UE2 } 8=100\end{array}$ & $\begin{array}{c}\mathrm{kg} / \\
\text { mieszkańca }\end{array}$ & $\begin{array}{l}\text { tony/ha } \\
\text { UR }\end{array}$ & tys. ton & $\begin{array}{c}\%, \\
\text { UE28 }=100\end{array}$ & $\begin{array}{c}\mathrm{kg} / \\
\text { mieszkańca }\end{array}$ & $\begin{array}{c}\text { tony/ha } \\
\text { UR }\end{array}$ \\
\hline UE-28 & 669207,11 & 100 & 1314 & 3,7 & 710712,36 & 100,0 & 1395 & 4,0 \\
\hline Austria & 9861,83 & 1,5 & 1142 & 3,6 & 15339,72 & 2,2 & 1777 & 5,6 \\
\hline Belgia & 14521,43 & 2,2 & 1288 & 10,9 & 18203,19 & 2,6 & 1615 & 13,7 \\
\hline Bułgaria & 11928,00 & 1,8 & 1662 & 2,4 & 10398,00 & 1,5 & 1449 & 2,1 \\
\hline Chorwacja & 4637,00 & 0,7 & 1102 & 3,0 & 5830,38 & 0,8 & 1386 & 3,8 \\
\hline Cypr & 476,90 & 0,1 & 563 & 3,8 & 236,37 & 0,0 & 279 & 1,9 \\
\hline Dania & 15522,75 & 2,3 & 2731 & 5,9 & 8810,89 & 1,2 & 1550 & 3,3 \\
\hline Estonia & 2027,44 & 0,3 & 1541 & 2,0 & 2283,90 & 0,3 & 1736 & 2,3 \\
\hline Finlandia & 5363,00 & 0,8 & 979 & 2,4 & 2617,00 & 0,4 & 478 & 1,2 \\
\hline Francja & 139805,10 & 20,9 & 2098 & 4,8 & 95425,96 & 13,4 & 1432 & 3,3 \\
\hline Grecja & 14784,54 & 2,2 & 1366 & 2,9 & 5395,94 & 0,8 & 499 & 1,1 \\
\hline Hiszpania & 66395,45 & 9,9 & 1429 & 2,8 & 43740,76 & 6,2 & 942 & 1,8 \\
\hline Holandia & 23342,66 & 3,5 & 1378 & 12,6 & 15665,95 & 2,2 & 925 & 8,5 \\
\hline Irlandia & 3414,82 & 0,5 & 735 & 0,8 & 29339,89 & 4,1 & 6314 & 6,6 \\
\hline Litwa & 8386,44 & 1,3 & 2887 & 2,8 & 10256,91 & 1,4 & 3531 & 3,4 \\
\hline Luksemburg & 139,50 & 0,0 & 245 & 1,1 & 837,39 & 0,1 & 1470 & 6,4 \\
\hline Łotwa & 4106,88 & 0,6 & 2077 & 2,2 & 2722,90 & 0,4 & 1377 & 1,4 \\
\hline Malta & 77,11 & 0,0 & 179 & 6,6 & 37,93 & 0,0 & 88 & 3,2 \\
\hline Niemcy & 96204,50 & 14,4 & 1178 & 5,8 & 147660,11 & 20,8 & 1808 & 8,8 \\
\hline Polska & 54591,14 & 8,2 & 1437 & 3,8 & 85858,54 & 12,1 & 2260 & 6,0 \\
\hline Portugalia & 7374,00 & 1,1 & 712 & 2,0 & 6019,12 & 0,8 & 581 & 1,6 \\
\hline Rep. Czesk & 14628,47 & 2,2 & 1387 & 4,2 & 10125,84 & 1,4 & 960 & 2,9 \\
\hline Rumunia & 33012,75 & 4,9 & 1666 & 2,4 & 25313,33 & 3,6 & 1277 & 1,8 \\
\hline Słowacja & 5952,82 & 0,9 & 1098 & 3,1 & 6505,34 & 0,9 & 1199 & 3,4 \\
\hline Słowenia & 1100,65 & 0,2 & 533 & 2,3 & 2961,92 & 0,4 & 1435 & 6,2 \\
\hline Szwecja & 9111,52 & 1,4 & 930 & 3,0 & 9697,77 & 1,4 & 990 & 3,2 \\
\hline Węgry & 20885,09 & 3,1 & 2122 & 3,9 & 16404,16 & 2,3 & 1667 & 3,1 \\
\hline Wlk. Brytania & 43280,87 & 6,5 & 665 & 2,5 & 84688,60 & 11,9 & 1300 & 4,9 \\
\hline Włochy & 58274,45 & 8,7 & 960 & 4,6 & 48334,55 & 6,8 & 796 & 3,8 \\
\hline
\end{tabular}

Źródło: opracowanie własne na podstawie danych EUROSTAT, 2018a.

Biorąc pod uwagę wolumen wytworzonej biomasy z roślin uprawnych w przeliczeniu na jednostkę powierzchni użytków rolnych należy stwierdzić, że średnia dla państw unijnych w 2015 roku wynosiła 3,7 ton/ha (tabela 2). Wśród krajów będących liderami w tym zakresie należy wymienić: Holandię (12,6 ton/ha), Belgię (10,9 ton/ha), Maltę $(6,6$ ton/ha), Danię (5,9 ton/ha) i Niemcy (5,8 ton/ha). Można stwierdzić, że są to państwa cechujące się relatywnie wysoką efektywnością wykorzystania czynnika produkcji w postaci ziemi. Do krajów charakteryzujących się ponadprzeciętnymi w stosunku do średniej unijnej wartościami analizowanego wskaźnika zaliczyć należy ponadto: Francję, Włochy, Republikę Czeską, Węgry, Polskę i Cypr. Warto jednak zauważyć, że wysoka wartość omawianego wskaźnika w odniesieniu do Malty, a także Cypru wynikała z relatywnie niewielkiego udziału tych krajów w strukturze użytków rolnych w UE.

Drugim rodzajem biomasy roślinnej jest biomasa pozyskiwana $\mathrm{z}$ resztek roślin uprawnych, z roślin pastewnych i biomasa wypasana. W państwach Unii Europejskiej w 2015 roku łącznie wytworzono 710 712,36 tys. ton tego typu biomasy, z czego największy udział miały następujące kraje: Niemcy (20,8\%), Francja (13,4\%), Polska $(12,1 \%)$, Wielka Brytania $(11,9)$ i Włochy $(6,8 \%)$ - tabela 2 . Łączny udział tych państw w 
wolumenie produkcji unijnej wyniósł blisko dwie trzecie $(65,0 \%)$. Można więc stwierdzić, że poziom koncentracji przestrzennej produkcji pozostałej biomasy był nieco większy niż biomasy pochodzącej z roślin uprawnych. Warto przy tym podkreślić wysoką lokatę Polski w zakresie ilości wytworzonej pozostałej biomasy roślinnej, co wynikało m.in. ze znacznego udziału naszego kraju w unijnym wolumenie pozyskiwania resztek pożniwnych, np. w postaci liści buraków cukrowych i pastewnych $(28,4 \%)$ czy słomy $(15,5 \%)$.

W 2015 roku średnia ilość biomasy pozyskiwanej z resztek roślin uprawnych, z roślin pastewnych i biomasy wypasanej wynosiła w Unii Europejskiej $1395 \mathrm{~kg}$ per capita (tab. 2). Liderem wśród państw unijnych była w odniesieniu do analizowanego miernika Irlandia $(6314 \mathrm{~kg})$, w której poziom średniej unijnej został kilkukrotnie przekroczony. Na kolejnych miejscach znalazła się Litwa $(3531 \mathrm{~kg})$, Polska $(2260 \mathrm{~kg})$, Niemcy (1808 kg) oraz Austria $(1777 \mathrm{~kg})$. Podobnie jak $\mathrm{w}$ odniesieniu do biomasy pozyskiwanej $\mathrm{z}$ roślin uprawnych można stwierdzić, że wysoka wartość wskaźnika dla Litwy wynikała z relatywnie niewielkiego udziału tego kraju w liczbie ludności Unii Europejskiej.

W 2015 roku efektywność wykorzystania czynnika ziemi mierzona wolumenem produkcji pozostałej biomasy pochodzenia roślinnego w przeliczeniu na hektar użytków rolnych wynosiła średnio w Unii Europejskiej 4 tony/ha (tabela 2). Najwyższą wartość omawianego wskaźnika odnotowano w Belgii (13,7 ton/ha), Niemczech $(8,8$ ton/ha), Holandii ( 8,5 ton/ha), Irlandii (6,6 ton/ha) oraz w Luksemburgu (6,4 ton/ha). W odniesieniu do Luksemburga wysoka wartość analizowanego wskaźnika była związana ze stosunkowo niewielkim udziałem tego państwa w unijnej strukturze użytków rolnych. Wśród krajów cechujących się ponadprzeciętnymi w stosunku do średniej unijnej wartościami badanego miernika wymienić należy ponadto: Słowenię, Polskę, Austrię i Wielką Brytanię.

W 2015 roku w państwach UE wyprodukowano łącznie 1379 919,47 tys. ton biomasy roślinnej (pochodzącej z roślin uprawnych i pozostałej biomasy), przy czym w pięciu krajach pozyskano łącznie $62,2 \%$, tj. w Niemczech (17,7\% wolumenu UE), Francji (17\%), Polsce $(10,2 \%)$, Wielskiej Brytanii $(9,3 \%)$, Hiszpanii $(8,0 \%)$. Po uwzględnieniu produkcji we Włoszech $(7,7 \%$ wolumenu UE) i Rumunii $(4,2 \%)$ należy stwierdzić, że w w/w państwach wytworzono blisko $3 / 4$ całości biomasy roślinnej pozyskanej w UE.

W toku badań wykazano występowanie istotnej statystycznie korelacji pomiędzy potencjałem ludnościowym kraju a wielkością produkcji biomasy (współczynnik korelacji Pearsona wyniósł 0,95); a także pomiędzy powierzchnią użytków rolnych a ilością wytworzonej biomasy (współczynnik korelacji wyniósł 0,89 ).

Na rysunku 1 zaprezentowano zależności pomiędzy wielkością produkcji biomasy (co odpowiada powierzchni kół) a potencjałem ludnościowym kraju (mierzonym udziałem w liczbie ludności UE) i potencjałem produkcyjnym rolnictwa (mierzonym udziałem w powierzchni użytków rolnych w UE). W ten sposób graficznie zaprezentowany podział krajów unijnych pozwala na wyznaczenie grup państw:

- państwa o największym potencjale w zakresie użytków rolnych - Francja i Hiszpania, przy czym pierwszy z krajów efektywnie wykorzystywał ten potencjał, natomiast udział Hiszpanii w produkcji biomasy roślinnej był znacznie niższy niż udział w powierzchni UR;

- państwa o największym potencjale ludnościowym - Niemcy, Wielka Brytania i Włochy, z których tylko w Niemczech ilość wytworzonej biomasy roślinnej odpowiadała udziałowi w liczbie mieszkańców UE; 
- Polska i Rumunia - cechujące się podobnym potencjałem produkcji roślinnej w rolnictwie, ale różniące znacznie potencjałem ludnościowym, co implikowało różnice w ilości produkowanej biomasy;

- pozostałe państwa UE - charakteryzujące się zarówno relatywnie niewielkim potencjałem ludnościowym i produkcyjnym, jak również stosunkowo niedużym udziałem w ilości wytworzonej biomasy roślinnej w UE.

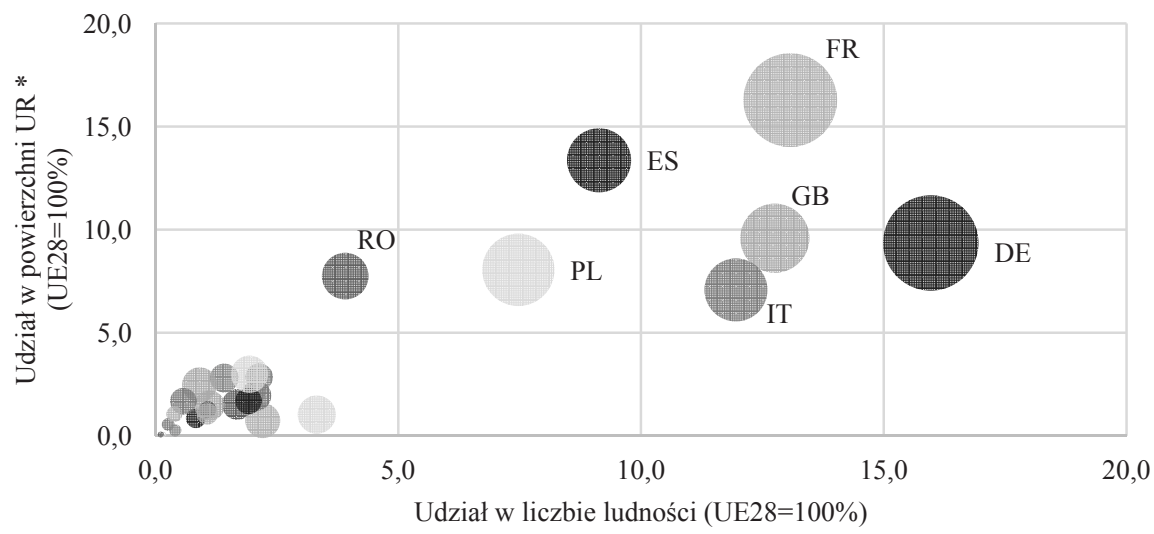

* - Powierzchnia kół odpowiada udziałowi danego państwa w produkcji biomasy roślinnej w UE (UE28=100\%) The wheel area corresponds to the share of a given country in production of plant biomass in the EU (UE28=100\%)

Rys. 1. Produkcja biomasy rolniczej pochodzenia roślinnego (z roślin uprawnych oraz pozostałej biomasy) w państwach UE na tle udziału w strukturze użytków rolnych oraz w strukturze ludności w 2015 roku

Fig. 1. Production of agricultural biomass of plant origin (from arable crops and other plant biomass) in EU countries against the background of the share in the structure of agricultural land and the population structure in 2015

Źródło: opracowanie własne na podstawie EUROSTAT, 2018a.

W literaturze brakuje opracowań dotyczących wykorzystania biomasy rolniczej w celach innych niż żywnościowe na poziomie Unii Europejskiej. Relatywnie często poruszana jest kwestia wykorzystania biomasy pochodzącej $\mathrm{z}$ rolnictwa na cele energetyczne m.in. $\mathrm{w}$ kontekście oceny potencjału energetycznego biomasy, możliwości redukcji emisji gazów cieplarnianych i unieszkodliwiania odpadów, czy oceny uwarunkowań rolnictwa dla produkcji energii odnawialnej z biomasy (Chauhan, 2012; Borsukiewicz-Gozdur i in., 2014; Weldemichael i Assefa, 2016; Baum i in., 2013; Weiland, 2006; Rosillo-Callea i Hall, 1992; Muller, 2009; Janiszewska i Ossowska, 2015; Galchynska i in., 2015; Jasiulewicz, 2014). Może to przyczyniać się do zawężonego rozumienia tego pojęcia. Warto podkreślić, że koncepcja biogospodarki opiera się na zrównoważonej produkcji i przekształcaniu biomasy w różnorodne bioprodukty (żywnościowe, zdrowotne, włókiennicze i przemysłowe), a także w energię. Klasyfikacja roślin uprawnych ze względu na możliwość ich wykorzystania na cele nieżywnościowe została zaprezentowana przez P. Gradziuka i Z. Wojtaszka (2002).

Zagadnienia dotyczące przekształcania biomasy na bioprodukty można odnaleźć w literaturze przede wszystkim w dwóch kontekstach. Pierwszy z nich dotyczy ogólnych rozważań na temat koncepcji biogospodarki, w ramach których podkreśla się rolę kreowania innowacyjnych bioproduktów przy wykorzystaniu wiedzy (Adamowicz, 2017; Krzywonos i in., 2016; Twardowski i Woźniak, 2016; Pasculea, 2015). Drugi natomiast 
obejmuje badania np. z zakresu nauk biologicznych, chemicznych, biotechnologicznych czy rolniczych dotyczące możliwości wykorzystania przemysłowego elementów biomasy rolniczej (Xu i in., 2008; Reddy i Yang, 2005; Gallezot, 2012; Szwach i Kulesza, 2014; Chyc i Ogonowski, 2014).

\section{Podsumowanie}

W niniejszym opracowaniu zaprezentowano różne podejścia do definiowania pojęcia biomasy wraz ze wskazaniem na potrzebę szerokiego jej ujmowania. Źródłem biomasy są bowiem produkty, odpady i pozostałości pochodzace z rolnictwa, leśnictwa, rybołówstwa, akwakultury oraz z produkcji przemysłowej i gospodarki komunalnej pod warunkiem ich organicznego pochodzenia i biodegradowalności. Biomasa może być wykorzystywana zarówno jako produkt finalny, jak również jako surowiec do wytwarzania innych produktów. Biomasa, w tym biomasa rolnicza - jako podstawowy surowiec wykorzystywany do produkcji żywności, pasz, nawozów, bioenergii i bioproduktów - stanowi czynnik warunkujący możliwość kreowania rozwoju w oparciu o koncepcję biogospodarki.

Celem opracowania była identyfikacja i ocena przestrzennego zróżnicowania produkcji biomasy rolniczej pochodzenia roślinnego w państwach UE, jako podstawowego surowca wykorzystywanego do wytwarzania bioproduktów oraz bioenergii. W opracowaniu analizom poddano wskaźniki struktury produkcji biomasy rolniczej pochodzenia roślinnego w Unii Europejskiej, wskaźniki gęstości i natężenia, a także wskaźnik korelacji Pearsona.

W toku przeprowadzonych badań stwierdzono, że w 2015 roku 51,5\% wytwarzanej w UE biomasy roślinnej w rolnictwie to produkty uboczne - pochodzące $\mathrm{z}$ resztek roślin uprawnych, $\mathrm{z}$ roślin pastewnych i biomasy wypasanej. Produkcja biomasy roślinnej cechowała się znacznym zróżnicowaniem przestrzennym. Do państw będących liderami w tym zakresie można zaliczyć: Niemcy, Francję, Polskę, Wielką Brytanię, Hiszpanię, Włochy i Rumunię, na terenie których wytworzono blisko 3/4 roślinnej biomasy w ramach UE. Są to kraje w sposób szczególny predestynowane do rozwoju w oparciu o koncepcje biogospodarki. Do grupy krajów będących liderami w zakresie wolumenu produkcji biomasy z roślin uprawnych zaliczono Francję, Niemcy, Hiszpanię, i Polskę (łączny udział tych pięciu krajów w wolumenie produkcji w UE wynosił $62,1 \%$ ), natomiast w odniesieniu do pozostałej biomasy: Niemcy, Francję, Polskę, Wielką Brytanię i Włochy (ich łączny udział w produkcji w UE wynosił $65,0 \%$ ).

Najwyższe ilości biomasy pozyskiwanej z roślin uprawnych 2015 roku w UE w przeliczeniu na mieszkańca odnotowano na Litwie, w Danii, na Wegrzech, we Francji i na Łotwie, natomiast w odniesieniu do pozostałej biomasy roślinnej (pochodzącej z resztek roślin uprawnych, $\mathrm{z}$ roślin pastewnych i biomasy wypasanej) w Irlandii, na Litwie, w Polsce, Niemczech i Austrii. Przy czym wysokie wartości wskaźnika dla Litwy i Łotwy są związane z relatywnie niewielkim udziałem tych państw w liczbie mieszkańców UE.

Najwyższą efektywnością wykorzystania czynnika ziemi (mierzoną wolumenem produkcji biomasy w przeliczeniu na hektar użytków rolnych) w odniesieniu do biomasy z roślin uprawnych cechowały się: Holandia, Belgia, Malta, Dania i Niemcy, natomiast w odniesieniu do pozostałej biomasy Belgia, Niemcy, Holandia, Irlandia i Luxemburg. Należy zauważyć, że wysoka wartość wskaźnika dla Malty i Luksemburga była związana ze stosunkowo niewielkim udziałem tych krajów w strukturze użytków rolnych w UE. 
W wyniku przeprowadzonych badań wykazano występowanie istotnej statystycznie korelacji pomiędzy potencjałem ludnościowym kraju a wielkością produkcji biomasy (współczynnik korelacji Pearsona wyniósł 0,95); a także pomiędzy powierzchnią użytków rolnych a ilością wytworzonej biomasy (współczynnik korelacji wyniósł 0,89). Analizom poddano również zależności pomiędzy wielkością produkcji biomasy, potencjałem ludnościowym kraju (mierzonym udziałem w liczbie ludności UE) i potencjałem produkcyjnym rolnictwa (mierzonym udziałem w powierzchni użytków rolnych w UE), co pozwoliło na wyznaczenie czterech grup państw.

Wśród kierunków dalszych badań można wymienić identyfikację i analizę przestrzennego zróżnicowania wolumenu produkcji rolniczej biomasy pochodzenia zwierzęcego, a także badania dotyczące ilości wytworzonej biomasy roślinnej i zwierzęcej na poziomie jednostek przestrzennych niższego szczebla, np. NUTS2.

\section{Literatura}

Adamowicz, M. (2017). Biogospodarka - koncepcja, zastosowanie i perspektywy (Bioeconomy - concept, application and perspectives). Zagadnienia Ekonomiki Rolnej 1(350), 29-49.

Baum, R., Wajszczuk, K., Pepliński, B., Wawrzynowicz, J. (2013). Potential For Agricultural Biomass Production for Energy Purposes in Poland: a Review. Contemporary Economics, 7 (1), 63-74.

Borsukiewicz-Gozdur, A., Wiśniewski, S., Mocarski, S., Bańkowski M. (2014). ORC power plant for electricity production from forest and agriculture biomass. Energy Conversion and Management, 87, 1180-1185.

Chauhan, S. (2012). District wise agriculture biomass resource assessment for power generation: A case study from an Indian state, Punjab. Biomass and Bioenergy, 37, 205-212.

Christmann, P. (2004). Towards a thematic strategy on the sustainable use of natural resources. The European Union 6th Environmental Action Programme. Working Group 1 - "Supply of Resources" Final Report.

Chyc, M., Ogonowski, J. (2014). Słonecznik bulwiasty źródłem cennych surowców dla przemysłu, szczególnie spożywczego, kosmetycznego i farmaceutycznego (Jerusalem Artichoke as a Source of Valuable Raw Material, Especially for Food, Pharmaceutical and Cosmetics Industries). Wiadomości Chemiczne, 68(7-8), 719-732.

Dyrektywa Parlamentu Europejskiego i Rady 2009/28/WE z dnia 23 kwietnia 2009 r. w sprawie promowania stosowania energii ze źródeł odnawialnych zmieniająca i w następstwie uchylająca dyrektywy 2001/77/WE oraz 2003/30/WE (Directive 2009/28/EC of the European Parliament and of the Council of 23 April 2009 on the promotion of the use of energy from renewable sources and amending and subsequently repealing Directives 2001/77/EC and 2003/30/EC), Dziennik Urzędowy Unii Europejskiej 5.6.2009.

EUROSTAT (2018a), Eurostat's Database, pobrane 31 stycznia 2018 roku z: http://ec.europa.eu/eurostat.

EUROSTAT (2018b), pobrane 4 lutego 2018 roku z: http://ec.europa.eu/eurostat/web/environmental-data-centreon-natural-resources/natural-resources/raw-materials/biomass.

Galchynska, J., Orlikowskyi, M., Maciejczak, M. (2015). Development of Bioenergy from Biomass in Ukraine. Scientific Journal WULS-SGGW Problems of World Agriculture, 15(4), 56-61.

Gallezot, P. (2012). Conversion of biomass to selected chemical products. Chemical Society Reviews, 41, 1538-1558.

Gradziuk, B., Gradziuk, P. (2015). Foreign trade of biomass for energy purposes in Poland in the years 20082014. Barometr Regionalny, 13(3), 153-159.

Gradziuk, P., Wojtaszek, Z. (2002). Alternatywne wykorzystanie gruntów rolniczych na cele niezwiązane z produkcją żywności (Alternative use of agricultural land for purposes unrelated to food production). W: B. Klepacki (red.) Procesy dostosowawcze produkcji roślinnej w Polsce w kontekście integracji z Unią Europejską (s. 213-228). Warszawa: Wieś Jutra Sp. z o.o.

Heinimö, J., Junginger, M. (2009). Production and trading of biomass for energy - An overview of the global status. Biomass and Bioenergy, 33 (9), 1310-1320.

Janiszewska, D., Ossowska, L. (2015). Zróżnicowanie uwarunkowań rolnictwa dla produkcji energii odnawialnej z biomasy rolniczej w krajach Unii Europejskiej (Diversification of Agricultural Determinants for Renewable Energy Production Using Agricultural Biomass in European Union Countries). $Z N S G G W$ Problemy Rolnictwa Światowego, 15(2), 75-84. 
Jarosz-Angowska, A. (2015). Zmiana znaczenia rolnictwa Unii Europejskiej na tle gospodarki światowej w latach 2000-2012 (Changing role of European Union agriculture on the background of global economy in the years 2000 $\square$ 2012). Annales Universitatis Mariae Curie-Skłodowska, Sectio H Oeconomia, 49(2), 61-71.

Jasiulewicz, M. (2014). Potencjał energetyczny biomasy rolniczej w aspekcie realizacji przez Polskę Narodowego Celu Wskaźnikowego OZE i dyrektyw UE w 2020 roku (The Energety Potential of Agriculture Biomass in Polish Regions in the Aspect of the Realize National Aim Index at the RES 2020 Year). Roczniki Naukowe Stowarzyszenia Ekonomistów Rolnictwa i Agrobiznesu, 16 (1), 70-76.

Krzywonos, M., Marciszewska, A., Domiter, M., Borowiak, D. (2016). Bioekonomia - stan obecny, kierunki zmian i perspektywy rozwoju. Wyzwanie dla uczelni, przedsiębiorców i administracji (Bio-economy current status, trends and prospects. The challenge for universities, businesses and government). Polish Journal of Agronomy, 27, 71-79.

Muller, A. (2009). Sustainable agriculture and the production of biomass for energy use. Climatic Change, 94(3-4), 319-331.

OECD (2004). Biomass and Agriculture. Sustainability, Markets and Policies.

Pasculea, M. (2015). Strategic options of public policy for developing the bioeconomy sector in Romania. Revista Romana de Economie, 41 (1),190-200.

Reddy, N., Yang, Y. (2005). Biofibers from agricultural byproducts for industrial applications. Trends in Biotechnology, 23 (1), 22-27.

Rosillo-Callea, F., Hall, D.O. (1992). Biomass energy, forests and global Warming. Energy Policy, 20 (2), 124136.

Rozporządzenie Ministra Gospodarki z dnia 18 października 2012 r. w sprawie szczegółowego zakresu obowiązków uzyskania i przedstawienia do umorzenia świadectw pochodzenia, uiszczenia opłaty zastępczej, zakupu energii elektrycznej i ciepła wytworzonych w odnawialnych źródłach energii oraz obowiązku potwierdzania danych dotyczących ilości energii elektrycznej wytworzonej w odnawialnym źródle energii (Dz.U. z 2012 r. poz. 1229).

Rozporządzenie Parlamentu Europejskiego i Rady (UE) nr 691/2011 z dnia 6 lipca 2011 r. w sprawie europejskich rachunków ekonomicznych środowiska (Tekst mający znaczenie dla EOG) (Regulation (EU) No 691/2011 of the European Parliament and of the Council of 6 July 2011 on European environmental economic accounts (Text with EEA relevance), Dz.U. L 192 z 22.7.2011.

Szwach, I., Kulesza, R. (2014). Potencjał biomasy w aspekcie otrzymywania wybranych surowców i produktów chemicznych (The Potential of Biomass for Obtaining of Raw Materials and Chemical Products). Chemik, 68(10), 893-900.

The European Bioeconomy in 2030. Delivering Sustainable Growth by addressing the Grand Societal Challenges. (2011). European Plant Science Organisation. Pobrano 5 lutego 2018 z: http://www.epsoweb.org/file/560.

Twardowski, T., Woźniak, E. (2016). Bioekonomia wokół nas (Bioeconomy around us). Nauka, 3, 147-160.

Ustawa z dnia 25 sierpnia 2006 r. o biokomponentach i biopaliwach ciekłych (Dz.U. $2006 \mathrm{Nr} 169$ poz. 1199).

Weiland, P. (2006). Biomass Digestion in Agriculture: A Successful Pathway for the Energy Production and Waste Treatment in Germany. Engineering in Life Sciences, 6 (3), 302-309. DOI: 10.1002/elsc.200620128.

Weldemichael, Y., Assefa, G. (2016). Assessing the energy production and GHG (greenhouse gas) emissions mitigation potential of biomass resources for Alberta. Journal of Cleaner Production, 5(112), 4257-4264.

Wilkin, J., (red.). (2010). Wielofunkcyjność rolnictwa. Kierunki badań, podstawy metodologiczne i implikacje praktyczne (Multifunctional Agriculture. Research Trends, Methodological Basis and Practical Implications). Warszawa: Instytut Rozwoju Wsi i Rolnictwa Polskiej Akademii Nauk.

Xu, Y., Hanna, M.A., Isom, L. (2008). "Green” Chemicals from Renewable Agricultural Biomass - A Mini Review. The Open Agriculture Journal, 2, 54-61.

\section{Do cytowania / For citation:}

Komor A. (2018). Przestrzenne zróżnicowanie produkcji biomasy rolniczej pochodzenia roślinnego w państwach UE w kontekście rozwoju biogospodarki. Problemy Rolnictwa Światowego, 18(1), 100-110; DOI: 10.22630/PRS.2018.18.1.9

Komor A. (2018). Spatial Diversification of Agricultural Biomass Production of Plant Origin in EU Countries in the Context of Bioeconomy Development (in Polish). Problems of World Agriculture, 18(1), 100-110; DOI: 10.22630/PRS.2018.18.1.9 